Article

\title{
Sequestration and Oxidation of Cr(III) by Fungal Mn Oxides with Mn(II) Oxidizing Activity
}

\author{
Ryohei Suzuki ${ }^{1}$, Yukinori Tani ${ }^{1,2}{ }^{*}$, Hirotaka Naitou ${ }^{1,2}$, Naoyuki Miyata ${ }^{3}$ and \\ Kazuya Tanaka ${ }^{4}$ \\ 1 Department of Environmental Health Sciences, Graduate School of Nutritional and Environmental Sciences, \\ University of Shizuoka, 52-1 Yada, Shizuoka 422-8526, Japan; s18306@u-shizuoka-ken.ac.jp (R.S.); \\ naitoh@u-shizuoka-ken.ac.jp (H.N.) \\ 2 Department of Environmental and Life Sciences, School of Food and Nutritional Sciences, University of \\ Shizuoka, 52-1 Yada, Shizuoka 422-8526, Japan \\ 3 Department of Biological Environment, Akita Prefectural University, Shimoshinjo-Nakano, Akita 010-0195, \\ Japan; nmiyata@akita-pu.ac.jp \\ 4 Advanced Science Research Center, Japan Atomic Energy Agency, Tokai, Ibaraki 319-1195, Japan; \\ tanaka.kazuya@jaea.go.jp \\ * Correspondence: taniy@u-shizuoka-ken.ac.jp; Tel.: +81-54-264-5797
}

Received: 10 December 2019; Accepted: 26 December 2019; Published: 31 December 2019

\begin{abstract}
Biogenic manganese oxides (BMOs) have gained increasing attention for environmental application because of their sequestration and oxidizing abilities for various elements. Oxidation and sequestration of $\mathrm{Cr}(\mathrm{III})$ by BMOs, however, still remain unknown. We prepared BMOs in liquid cultures of Acremonium strictum strain KR21-2, and subsequently conducted single or repeated treatment experiments in $\mathrm{Cr}\left(\mathrm{NO}_{3}\right)_{3}$ at $\mathrm{pH}$ 6.0. Under aerobic conditions, newly formed BMOs exhibited a rapid production of $\mathrm{Cr}(\mathrm{VI})$ without a significant release of $\mathrm{Mn}(\mathrm{II})$, demonstrating that newly formed BMO mediates a catalytic oxidation of $\mathrm{Cr}$ (III) with a self-regeneration step of reduced $\mathrm{Mn}$. In anaerobic solution, newly formed BMOs showed a cessation of $\mathrm{Cr}(\mathrm{III})$ oxidation in the early stage of the reaction, and subsequently had a much smaller $\mathrm{Cr}(\mathrm{VI})$ production with significant release of reduced $\mathrm{Mn}(\mathrm{II})$. Extraordinary sequestration of $\mathrm{Cr}$ (III) was observed during the repeated treatments under anaerobic conditions. Anaerobically sequestered $\mathrm{Cr}$ (III) was readily converted to $\mathrm{Cr}(\mathrm{VI})$ when the conditions became aerobic, which suggests that the surface passivation is responsible for the anaerobic cessation of $\mathrm{Cr}$ (III) oxidation. The results presented herein increase our understanding of the roles of $\mathrm{BMO}$ in $\mathrm{Cr}(\mathrm{III})$ oxidation and sequestration processes in potential application of BMOs towards the remediation of $\mathrm{Cr}(\mathrm{III}) / \mathrm{Cr}(\mathrm{VI})$ in contaminated sites.
\end{abstract}

Keywords: $\mathrm{Cr}(\mathrm{III})$ oxidation; $\mathrm{Cr}(\mathrm{III})$ sequestration; $\mathrm{Cr}(\mathrm{VI})$; biogenic manganese oxide; Mn(II)-oxidizing fungi

\section{Introduction}

Chromium ( $\mathrm{Cr}$ ) is widely used in various industries such as electroplating, pigment production, wood preservation, tanning of animal hides, etc. [1,2]. Concomitant anthropogenic emissions of $\mathrm{Cr}$ into the environment have increasingly induced a significant environmental concern because of the potential toxicity of Cr toward humans [3], fishes [4], and plants [5-7]. Therefore, development of cost-effective remediation systems for $\mathrm{Cr}$ is urgently needed $[8,9]$.

In natural environments, $\mathrm{Cr}$ exists as trivalent $(\mathrm{Cr}[\mathrm{III}])$ and hexavalent $(\mathrm{Cr}[\mathrm{VI}])$ forms which have quite different physicochemical properties. Although $\mathrm{Cr}(\mathrm{III})$ is less toxic and nutritionally essential for some organisms, including humans, large amounts of $\mathrm{Cr}$ (III) can cause health problems such as lung 
cancer [1]. $\mathrm{Cr}(\mathrm{VI})$ is more toxic and labile, and exists as hydrochromate $\left(\mathrm{HCrO}_{4}{ }^{-}\right)$, chromate $\left(\mathrm{CrO}_{4}{ }^{2-}\right)$, and dichromate $\left(\mathrm{Cr}_{2} \mathrm{O}_{7}{ }^{2-}\right)$ ions, with domination of chromate $\left(\mathrm{CrO}_{4}{ }^{2-}\right)$ at neutral $\mathrm{pH}$ [1]. Many studies have focused on the oxidative transformation of $\mathrm{Cr}(\mathrm{III})$ to $\mathrm{Cr}(\mathrm{VI})$ by manganese oxide $\left(\mathrm{MnO}_{2}\right)$, because $\mathrm{MnO}_{2}$ is considered to be the only naturally existing oxidizer of $\mathrm{Cr}$ (III) to $\mathrm{Cr}$ (VI) [1], and so affects $\mathrm{Cr}$ (III) cycling in the environment. Under circumneutral conditions, microbial oxidation of $\mathrm{Mn}$ (II) proceeds several orders of magnitude faster than abiotic oxidation (such as homogenous and mineral surface-catalytic reactions; $[10,11])$, participating directly in the production of Mn oxide minerals in aquatic [12,13] and soil/subsurface [14-16] environments. Consequently, transformation of $\mathrm{Cr}$ (III) to $\mathrm{Cr}(\mathrm{VI})$, although indirectly, is primarily controlled by microbial Mn oxidizing activity, as demonstrated in culture experiments using Mn(II)-oxidizing bacteria including Pseudomonas putida GB-1 [17] and MnB-1 [18], Bacillus sp. SG-1 [19] and WH4 [20], and Rosebacter sp. Azwk-3b [21]. Among these studies, higher efficiencies of oxidative transformation by biogenic Mn oxide (BMO: abbreviations used in this study are listed in Supplementary Materials) compared to chemically synthetic $\mathrm{MnO}_{2}$ particles have been shown $[17,20]$. Although physicochemical features of BMOs (poorly crystalline, larger density of structural Mn(IV) vacancies, small domain size, etc. $[10,11])$ may partly cause their higher efficiencies $[17,20]$, detailed mechanisms for efficient oxidative $\mathrm{Cr}(\mathrm{III})$ transformation by BMOs remain to be elucidated.

Oxidative reaction of $\mathrm{Cr}(\mathrm{III})$ on the chemically synthetic $\mathrm{MnO}_{2}$ is generally susceptible to cessation during the early stage of the reaction at circumneutral $\mathrm{pH}$ condition (commonly at $\mathrm{pH}>5$ ) even when excessive amounts of unreacted $\mathrm{MnO}_{2}$ remain [22-26]. The cause for this cessation in $\mathrm{Cr}$ (III) oxidation remains uncertain $[25,26]$. Our previous studies using newly formed BMOs prepared by a Mn(II)-oxidizing fungus, Acremonium strictum KR21-2 [27], have demonstrated that the cessation of oxidative transformations of $\mathrm{As}(\mathrm{III})$ to $\mathrm{As}(\mathrm{V})[28,29]$ and of $\mathrm{Co}(\mathrm{II})$ to $\mathrm{Co}(\mathrm{III})$ [30] by fungal BMOs is readily recovered through the self-regeneration of reduced $\mathrm{Mn}$ (II) or $\mathrm{Mn}$ (III) by the associated $\mathrm{Mn}$ (II) oxidase activity in newly formed BMOs. We therefore hypothesized that the newly formed BMOs can effectively convert $\mathrm{Cr}(\mathrm{III})$ to $\mathrm{Cr}(\mathrm{VI})$ without the cessation if the $\mathrm{Mn}(\mathrm{II})$ oxidase associated in BMOs is active to reduce the surface passivation. However, the role of enzymatic activity in $\mathrm{Cr}$ (III) oxidation process remains unclear.

Kinetics of oxidative transformation of $\mathrm{Cr}$ (III) may be affected by the sorption affinity of $\mathrm{Cr}$ (III) on BMO because it requires electron transfer from $\mathrm{Cr}$ (III) to the structural Mn(IV) in BMO. Because BMOs possess sheet (vernadite/birnessite-like) structures with nano-sized domains and high vacant site density for structural Mn(IV) [31,32], subsequently they show high sorption affinity for, especially, various cationic species such as $\mathrm{Pb}^{2+}$ [33-35], $\mathrm{Zn}^{2+}$ [36-39], $\mathrm{Cd}^{2+}[40,41], \mathrm{Ni}^{2+}[41,42], \mathrm{Co}^{2+}[30,43]$, and rare earth element $\left(\mathrm{REE}^{3+}\right)$ ions $[44,45]$. Sorption of $\mathrm{Mn}^{2+}$ and $\mathrm{Zn}^{2+}$ was demonstrated to lower the oxidation kinetics of $\mathrm{As}(\mathrm{III})$ to $\mathrm{As}(\mathrm{V})$ on $\mathrm{BMO}$, likely due to the blocking of the redox-active sites on BMOs [28,29]. At circumneutral $\mathrm{pH}$ in aqueous solutions, $\mathrm{Cr}^{3+}$ can be readily hydrolyzed to form monomers such as $[\mathrm{Cr}(\mathrm{OH})]^{2+}$ and $\left[\mathrm{Cr}(\mathrm{OH})_{2}\right]^{+}$as well as oligomers as dimeric $\left[\mathrm{Cr}_{2}(\mathrm{OH})_{2}\right]^{4+}$, trimeric $\left[\mathrm{Cr}_{3}(\mathrm{OH})_{4}\right]^{5+}$, and tetrametric $\left[\mathrm{Cr}_{4}(\mathrm{OH})_{6}\right]^{6+}[46-49]$, and may be sequestered on BMO surface. Although these polynuclear $\mathrm{Cr}(\mathrm{III})$ species may eventually precipitate as $\mathrm{Cr}(\mathrm{OH})_{3}$, Saleh et al. [48] and Hu et al. [50] demonstrated that such polymeric $\mathrm{Cr}$ (III) complexes exist in aqueous solution for relatively long time periods. Sequestration (sorption/precipitation) properties of such polymetric $\mathrm{Cr}(\mathrm{III})$ species on BMOs remain unknown and may be a key to remediating $\mathrm{Cr}$ contamination by BMOs.

The aim of this study was to clarify the role of fungal $\mathrm{Mn}$ (II) oxidase activity in newly formed BMOs on oxidative transformation of $\mathrm{Cr}(\mathrm{III})$ to $\mathrm{Cr}(\mathrm{VI})$ as well as in $\mathrm{Cr}(\mathrm{III})$ sequestration, which were generated in batch cultures of $A$. strictum KR21-2 [51,52]. The enzymatically inactive BMOs $[27,53]$ were prepared by heat treatment, or by deaeration to remove dissolved oxygen, a terminal electron acceptor for enzymatic Mn(II) oxidation, and were used for the experiments to determine whether the enzymatic activity affected the oxidation of $\mathrm{Cr}(\mathrm{III})$ to $\mathrm{Cr}(\mathrm{VI})$ and concomitant $\mathrm{Cr}$ sequestration. 


\section{Results and Discussion}

\subsection{Cr(III) Oxidation Efficiency of Newly Formed BMOs with an Enzymatic Mn(II)-Oxidizing Activity}

We conducted the treatment experiments of $\mathrm{Cr}\left(\mathrm{NO}_{3}\right)_{3}$ by newly formed BMO under aerobic condition to clear $\mathrm{Cr}$ (III) oxidation efficiency by newly formed $\mathrm{BMO}$ at $\mathrm{pH} 6.0$ where the enzymatic $\mathrm{Mn}$ (II)-oxidizing activity is active to readily oxidize $\mathrm{Mn}^{2+}$ to insoluble $\mathrm{Mn}$ oxide [54]. When newly formed BMOs ( $1 \mathrm{mM}$ as $\mathrm{Mn}$ ) were reacted with $0.1-0.5 \mathrm{mM} \mathrm{Cr}\left(\mathrm{NO}_{3}\right)_{3}$ in $100 \mathrm{mM}$ 2-morpholinoethanesulfonic acid (MES) buffer ( $\mathrm{pH}$ at 6.0) under aerobic conditions, rapid production of $\mathrm{Cr}(\mathrm{VI})$ dissolved $\left(\mathrm{Cr}^{\mathrm{VI}}{ }_{\text {diss }}\right.$ ) was observed within the first 4-h reaction (Figure 1), and then gradually increased to $79 \%-86 \%$ of the initial $\mathrm{Cr}$ (III) $\left(\mathrm{Cr}^{\mathrm{III}}\right.$ Int $)$ at $24 \mathrm{~h}$ (Figure $1 \mathrm{E}$ and Table S1). This indicates that they readily convert $\mathrm{Cr}(\mathrm{III})$ to $\mathrm{Cr}(\mathrm{VI})$ at $\mathrm{pH}$ 6.0, whereas chemically synthesized $\mathrm{MnO}_{2}$ commonly ceases the $\mathrm{Cr}(\mathrm{III})$ oxidation reaction at $\mathrm{pH}>5$ [22,23]. At $\mathrm{pH} 6.0, \mathrm{HCr}^{\mathrm{VI}} \mathrm{O}_{4}{ }^{-}(76 \%)$ and $\mathrm{Cr}^{\mathrm{VI}} \mathrm{O}_{4}{ }^{2-}(24 \%)$ coexists [55] according to the following acid dissociation equilibrium [56].

$$
\begin{gathered}
\mathrm{H}_{2} \mathrm{CrO}_{4}(\mathrm{aq}) \rightarrow \mathrm{H}^{+}(\mathrm{aq})+\mathrm{HCrO}_{4}{ }^{-}(\mathrm{aq}) \mathrm{pK} \mathrm{a}=0.2 \\
\mathrm{HCrO}_{4}{ }^{-}(\mathrm{aq}) \rightarrow \mathrm{H}^{+}(\mathrm{aq})+\mathrm{CrO}_{4}{ }^{2-}(\mathrm{aq}) \mathrm{pK}_{\mathrm{a} 2}=6.5
\end{gathered}
$$

Thus, oxidation reactions of $\mathrm{Cr}(\mathrm{III})$ to $\mathrm{Cr}(\mathrm{VI})$ by $\mathrm{MnO}_{2}$ can be expressed as Equations (3) and (4) and their stoichiometry expects $\mathrm{Cr}^{\mathrm{VI}}$ diss with the molar ratio relative to $\mathrm{Mn}^{2+}$ release $\left(\mathrm{Mn}^{\mathrm{II}}\right.$ rel $)$ at $\mathrm{Cr}_{\text {diss }}^{\mathrm{VI}} / \mathrm{Mn}^{\mathrm{II}}{ }_{\text {rel }}=0.67$.

$$
\begin{aligned}
& \mathrm{Cr}^{3+}(\mathrm{aq})+1.5 \mathrm{Mn}^{\mathrm{IV}} \mathrm{O}_{2}(\mathrm{~s})+\mathrm{H}_{2} \mathrm{O}(\mathrm{aq}) \rightarrow \mathrm{HCr}^{\mathrm{VI}} \mathrm{O}_{4}{ }^{-}(\mathrm{aq})+1.5 \mathrm{Mn}^{2+}(\mathrm{aq})+\mathrm{H}^{+}(\mathrm{aq}) \\
& \mathrm{Cr}^{3+}(\mathrm{aq})+1.5 \mathrm{Mn}^{\mathrm{IV}} \mathrm{O}_{2}(\mathrm{~s})+\mathrm{H}_{2} \mathrm{O}(\mathrm{aq}) \rightarrow \mathrm{Cr}^{\mathrm{VI}} \mathrm{O}_{4}{ }^{2-}(\mathrm{aq})+1.5 \mathrm{Mn}^{2+}(\mathrm{aq})+2 \mathrm{H}^{+}(\mathrm{aq})
\end{aligned}
$$

However, throughout the treatments, the $\mathrm{Mn}(\mathrm{II})$ concentrations released $\left(\mathrm{Mn}^{\mathrm{II}}{ }_{\text {rel }}\right)$ from the BMO phase were consistently lower than $0.005 \mathrm{mM}$ (Figure S1 and Table S1), which is two orders of magnitude less than the calculated values from Equations (3) and (4). In the case of the aerobic treatments, in $0.5 \mathrm{mM} \mathrm{Cr}{ }^{\mathrm{III}}$ Int (i.e., the highest concentration in this experiment) the observed $\mathrm{Cr}^{\mathrm{VI}}{ }_{\text {diss }}$ and $\mathrm{Mn}^{\mathrm{II}}$ rel were $0.39 \mathrm{mM}$ and $<0.005 \mathrm{mM}$ (Table S1), respectively, giving the $\mathrm{Cr}^{\mathrm{VI}}{ }_{\text {diss }} / \mathrm{Mn}^{\mathrm{II}}$ rel ratio of $>78$. Newly formed BMOs effectively oxidize exogenous $\mathrm{Mn}^{2+}$ through the enzymatic $\mathrm{Mn}(\mathrm{II})$-oxidizing activity maintained in the $\mathrm{BMO}$ under aerobic conditions at $\mathrm{pH} 6.0[27,45,54]$ as:

$$
2 \mathrm{Mn}^{2+}(\mathrm{aq})+\mathrm{O}_{2}(\mathrm{aq})+2 \mathrm{H}_{2} \mathrm{O}(\mathrm{aq}) \rightarrow 2 \mathrm{Mn}^{\mathrm{IV}} \mathrm{O}_{2}(\mathrm{~s})+4 \mathrm{H}^{+}(\mathrm{aq})
$$

The observed $\mathrm{Cr}^{\mathrm{VI}}$ diss $/ \mathrm{Mn}^{\mathrm{II}}$ rel ratio suggests the effective reoxidation of $\mathrm{Mn}^{2+}$ (and intermediate $\mathrm{Mn}^{\mathrm{III}}$ ) that was produced by the redox reaction with $\mathrm{Cr}(\mathrm{III})$, through $\mathrm{Mn}(\mathrm{II})$-oxidizing enzyme activity. Thus, the enzymatically active BMOs act as a catalytic agent for $\mathrm{Cr}$ (III) oxidation with the terminal electron acceptor of dissolved $\mathrm{O}_{2}$, by which homogeneous oxidation of $\mathrm{Cr}$ (III) does not proceed under the same conditions (Figure S2A). Our previous results have demonstrated such catalytic oxidation processes of $\mathrm{As}$ (III) to $\mathrm{As}(\mathrm{V})$ [29] and of $\mathrm{Co}(\mathrm{II})$ to $\mathrm{Co}(\mathrm{III})$ [30] (as the terminal electron acceptor of dissolved $\mathrm{O}_{2}$ ) using newly formed BMOs, which continuously mediates the oxidation reactions without release of reduced Mn. Enzymatically active BMOs also performed, through catalytic mediation, effective $\mathrm{Ce}(\mathrm{III})$ to $\mathrm{Ce}(\mathrm{IV})$ oxidation with a lower release of $\mathrm{Mn}(\mathrm{II})$, where the Ce oxidized/Mn released molar of $>200$ [54]. 

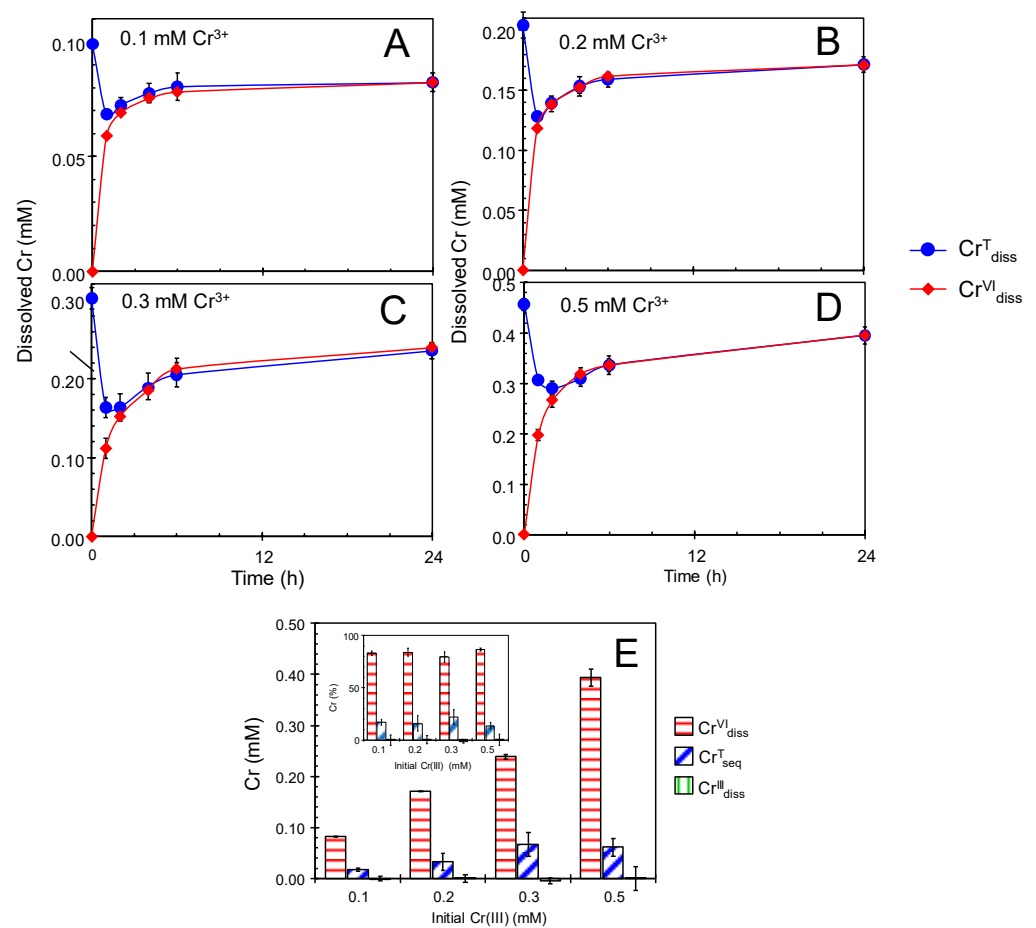

Figure 1. Single treatment of newly formed biogenic manganese oxides (BMOs; $1 \mathrm{mM}$ as Mn) with 0.1-0.5 mM Cr( $\left(\mathrm{NO}_{3}\right)_{3}$ under aerobic conditions at pH 6.0 (100 mM morpholinoethanesulfonic acid [MES] buffer). (A-E) Concentations of total $\mathrm{Cr}$ dissolved $\left(\mathrm{Cr}^{\mathrm{T}}{ }_{\text {diss }}\right)$ and $\mathrm{Cr}(\mathrm{VI})$ dissolved $\left(\mathrm{Cr}^{\mathrm{VI}}{ }_{\text {diss }}\right)$. Initial $\mathrm{Cr}\left(\mathrm{NO}_{3}\right)_{3}$ concentrations were: (A) $0.1 \mathrm{mM}$, (B) $0.2 \mathrm{mM}$, (C) $0.3 \mathrm{mM}$, and (D) $0.5 \mathrm{mM}$. (E) Concentrations (inset: percentages) of total $\mathrm{Cr}$ sequestered $\left(\mathrm{Cr}^{\mathrm{T}}{ }_{\text {seq }}\right), \mathrm{Cr}(\mathrm{VI})$ dissolved $\left(\mathrm{Cr}^{\mathrm{VI}}{ }_{\text {diss }}\right)$, and $\mathrm{Cr}(\mathrm{III})$ dissolved $\left(\mathrm{Cr}^{\mathrm{III}}\right.$ diss $)$ after the treatments. Data are shown as mean \pm standard deviation $(\mathrm{n}=3)$.

Repeated treatments of newly formed BMO in $0.1 \mathrm{mM} \mathrm{Cr}\left(\mathrm{NO}_{3}\right)_{3}(100 \mathrm{mM}$ MES at $\mathrm{pH}$ 6.0) solution with renewal of the bathing solution every $24 \mathrm{~h}$ confirmed that the catalytic $\mathrm{Cr}$ (III) oxidation by newly formed $\mathrm{BMO}$ continued for least 18 days (Figure 2). Following each treatment, the $\mathrm{Cr}^{\mathrm{VI}}$ diss concentration ranged from $0.097 \pm 0.003 \mathrm{mM}$ for the 5th treatment to $0.068 \pm 0.002 \mathrm{mM}$ for the last treatments, whereas $\mathrm{Mn}^{\mathrm{II}}{ }_{\text {rel }}$ was $<0.008 \mathrm{mM}$ throughout, resulting in $\mathrm{Cr}^{\mathrm{VI}}{ }_{\text {diss }} / \mathrm{Mn}^{\mathrm{II}}{ }_{\text {rel }}$ molar ratios from $150 \pm 9$ (1st treatment) to $8.6 \pm 0.8$ (last treatment). Decrease in $\mathrm{Cr}^{\mathrm{VI}}{ }_{\text {diss }} / \mathrm{Mn}^{\mathrm{II}}$ rel molar ratios suggests that the Mn(II) oxidizing activity in BMOs gradually weakened as the treatment was repeatedly conducted. Even in the last treatment, the $\mathrm{Cr}^{\mathrm{VI}}$ diss $/ \mathrm{Mn}^{\mathrm{II}}$ rel molar ratios were still higher than was expected from the redox stoichiometry of $\mathrm{Cr}^{\mathrm{VI}}$ diss $/ \mathrm{Mn}^{\mathrm{II}}$ rel at 0.67 (Equations (3) and (4)). In this repeated treatment, the oxidative conversion $\left(\mathrm{Cr}^{\mathrm{VI}}\right.$ diss relative to $\left.\mathrm{Cr}^{\mathrm{III}} \mathrm{Int}\right)$ was higher than $66 \% \pm 1 \%$ for each treatment with the cumulative conversion of $86 \% \pm 1 \%$ for 18 days (Figure 2 ). When newly formed BMO (1 mM as Mn) was repeatedly treated in a higher concentration of $\mathrm{Cr}\left(\mathrm{NO}_{3}\right)_{3}$ at $0.5 \mathrm{mM}(100$ mM MES at $\mathrm{pH}$ 6.0), conversion of $\mathrm{Cr}^{\mathrm{III}}$ Int to $\mathrm{Cr}^{\mathrm{VI}}$ diss was high at $86 \% \pm 2 \%$ and $90 \% \pm 2 \%$ for the 1 st and 2nd treatments, respectively, without significant release of $\mathrm{Mn}(\mathrm{II})\left(\mathrm{Mn}^{\mathrm{II}}\right.$ rel) (Figure 3 and Table S2). This shows the ability of newly formed BMOs to oxidize $\mathrm{Cr}$ (III) in these $\mathrm{Cr}^{\mathrm{III}}$ Int concentration ranges, in which some $\mathrm{Mn}$ (II)-oxidizing bacteria commonly lost growth and/or Mn(II)-oxidizing abilities; Psedomonas putida MnB-1 growth is partly inhibited at $0.2 \mathrm{mM}$ and totally inhibited at 0.5 mM Cr(III) [18]. Murray et al. [17], also reported $\mathrm{Cr}(\mathrm{III})$ and $\mathrm{Cr}(\mathrm{VI})$ toxicity on Psedomonas putida GB-1 growth at concentrations $\geq 0.01 \mathrm{mM}$. Preformation of fungal BMOs in the culture without any $\mathrm{Cr}(\mathrm{III}) / \mathrm{Cr}(\mathrm{VI})$ can prevent the inhibitory effect of $\mathrm{Cr}$ and subsequently make the microbially-mediated $\mathrm{Cr}(\mathrm{III})$ oxidation sufficient, even at a high $\mathrm{Cr}(\mathrm{III})$ concentration. In the 3rd treatment, however, a smaller conversion $(19 \% \pm 0 \%)$ was observed (Figure 3), which was likely due to inhibitory effects through the exposure of higher $\mathrm{Cr}(\mathrm{III})$ and/or $\mathrm{Cr}(\mathrm{VI})$ concentrations on enzymatic $\mathrm{Mn}$ (II) oxidation. 


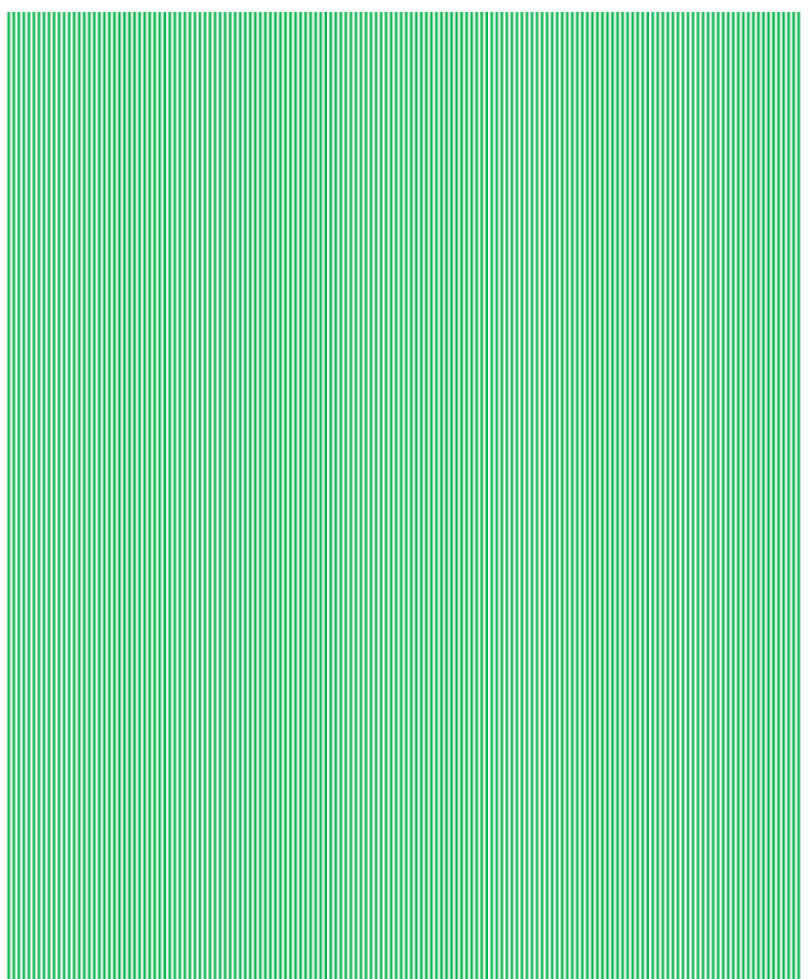

Figure 2. Repeated treatments of newly formed biogenic manganese oxides (BMOs; $1 \mathrm{mM}$ as $\mathrm{Mn}$ ) with $0.1 \mathrm{mM} \mathrm{Cr}\left(\mathrm{NO}_{3}\right)_{3}$ under aerobic conditions at $\mathrm{pH} 6.0$ (100 mM MES buffer). (A) Concentrations of initial $\mathrm{Cr}(\mathrm{III})\left(\mathrm{Cr}^{\mathrm{III}}{ }_{\text {Int }}\right)$, total $\mathrm{Cr}$ dissolved $\left(\mathrm{Cr}^{\mathrm{T}}{ }_{\text {diss }}\right), \mathrm{Cr}(\mathrm{VI})$ dissolved $\left(\mathrm{Cr}^{\mathrm{VI}}\right.$ diss $)$, and $\mathrm{Mn}(\mathrm{II})$ released $\left(\mathrm{Mn}^{\mathrm{II}}{ }_{\text {rel }}\right)$. (B) Molar ratio of $\mathrm{Cr}^{\mathrm{VI}}{ }_{\text {diss }} / \mathrm{Mn}^{\mathrm{II}}{ }_{\text {rel }}$. (C) Percentages of conversion to $\mathrm{Cr}^{\mathrm{VI}}$ diss. Bathing solutions were renewed every $24 \mathrm{~h}$ for 18 days. Data are shown as mean \pm standard deviation $(n=3)$.

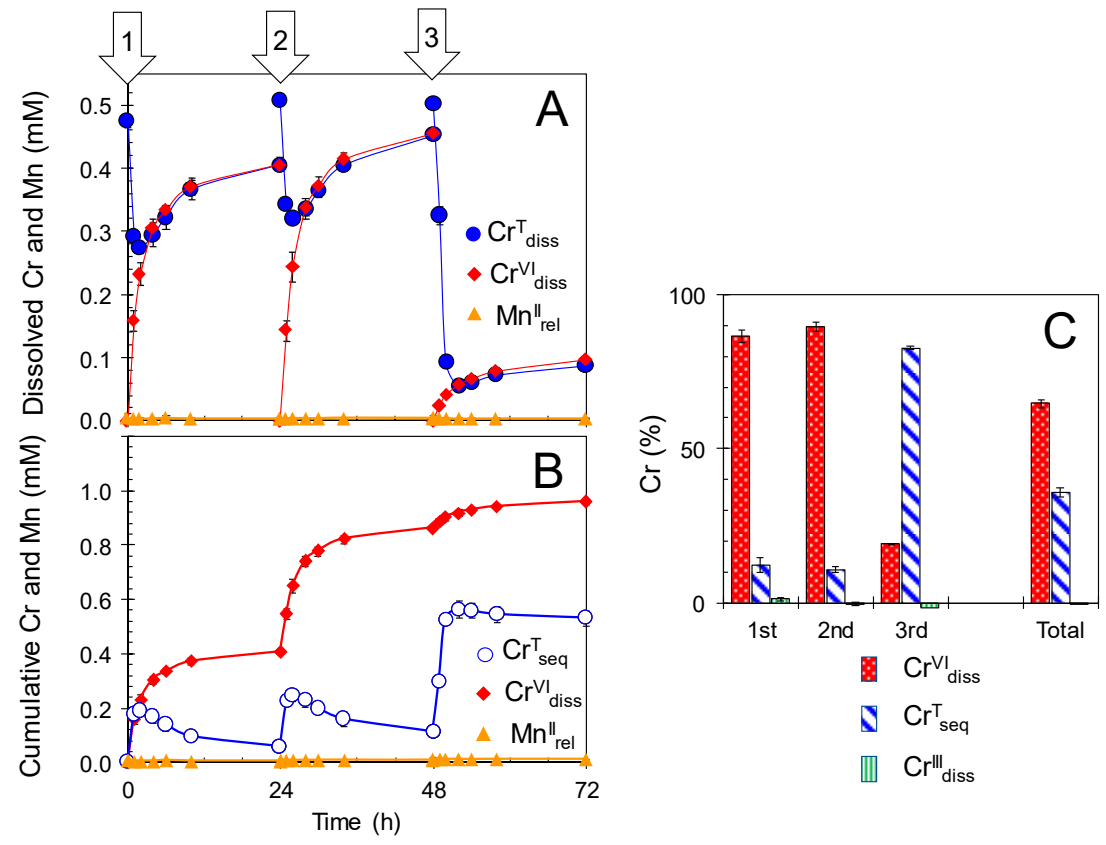

Figure 3. Repeated treatments of newly formed biogenic manganese oxides (BMOs; $1 \mathrm{mM}$ as Mn) with $0.5 \mathrm{mM} \mathrm{Cr}\left(\mathrm{NO}_{3}\right)_{3}$ under aerobic conditions at pH 6.0 (100 mM MES buffer). (A) Concentrations of total $\mathrm{Cr}$ dissolved $\left(\mathrm{Cr}^{\mathrm{T}}\right.$ diss $), \mathrm{Cr}(\mathrm{VI})$ dissolved $\left(\mathrm{Cr}^{\mathrm{VI}}{ }_{\text {diss }}\right)$, and $\mathrm{Mn}(\mathrm{II})$ released $\left(\mathrm{Mn}^{\mathrm{II}}{ }_{\text {rel }}\right)$. (B) Cumulative concentrations of total $\mathrm{Cr}$ sequestered $\left(\mathrm{Cr}^{\mathrm{T}}\right.$ seq $), \mathrm{Cr}^{\mathrm{VI}}{ }_{\text {diss }}$, and $\mathrm{Mn}^{\mathrm{II}}$ rel $\cdot(\mathbf{C})$ Percentages of $\mathrm{Cr}^{\mathrm{VI}}{ }_{\text {diss }}, \mathrm{Cr}^{\mathrm{T}}{ }_{\text {seq }}$, and $\mathrm{Cr}(\mathrm{III})$ dissolved $\left(\mathrm{Cr}^{\mathrm{III}}\right.$ diss $)$ during the repeated treatments. Bathing solutions were renewed every $24 \mathrm{~h}$ for 3 days (indicated by arrows). Data are shown as mean \pm standard deviation $(n=3)$. 


\subsection{Cessation of $\mathrm{Cr}(\mathrm{III})$ Oxidation by BMOs under Anaerobic Condition}

Under anaerobic condition, enzymatic Mn(II) oxidation is suppressed due to the lack of dissolved $\mathrm{O}_{2}$ as the terminal electron acceptor [27]. Anaerobic treatments of newly formed $\mathrm{BMO}$ in $\mathrm{Cr}\left(\mathrm{NO}_{3}\right)_{3}$ were conducted to deduce the $\mathrm{Cr}$ (III) oxidation efficiency when the catalytic mediation for $\mathrm{Cr}(\mathrm{III})$ oxidation by BMOs was inactive. Single treatment of newly formed BMOs ( $1 \mathrm{mM}$ as $\mathrm{Mn}$ ) with anaerobic 0.1-0.5 mM Cr$\left(\mathrm{NO}_{3}\right)_{3}\left(100 \mathrm{mM}\right.$ MES at $\mathrm{pH}$ 6.0) showed that $\mathrm{Cr}^{\mathrm{VI}}$ diss production ceased within the first $2 \mathrm{~h}$ of the treatment (Figure 4$)$ and accompanied significant release of $\mathrm{Mn}(\mathrm{II})\left(\mathrm{Mn}^{\mathrm{II}}{ }_{\mathrm{rel}}\right)(0.02-0.03 \mathrm{mM})$, because BMOs failed to reoxidize $\mathrm{Mn}^{\mathrm{II}}$ rel (Figure S1B). The anaerobic cessation of $\mathrm{Cr}$ (III) oxidation resulted in much lower $\mathrm{Cr}^{\mathrm{VI}}$ diss concentrations, ranging from $0.03\left(0.1 \mathrm{mM} \mathrm{Cr}{ }^{\mathrm{III}}{ }_{\mathrm{Int}}\right)$ to $0.05 \mathrm{mM}(0.5 \mathrm{mM}$ $\mathrm{Cr}^{\mathrm{III}}$ Int ) (Figure 4E and Table S1), demonstrating an important role of enzymatic $\mathrm{Mn}$ (II) oxidation for continuous mediation of $\mathrm{Cr}$ (III) oxidation by BMOs. Cessation of $\mathrm{Cr}$ (III) oxidation has been found for chemically synthesized Mn oxides [22-26], even under aerobic condition at $\mathrm{pH}>5$. In fact, heated BMOs, in which the enzymatic Mn(II) oxidizing activities were inactivated [27], showed cessation of $\mathrm{Cr}$ (III) oxidation (Figure 5) and concomitant Mn(II) release (Figure S1C) even under aerobic conditions, in a similar manner as abiotic Mn oxide phases.
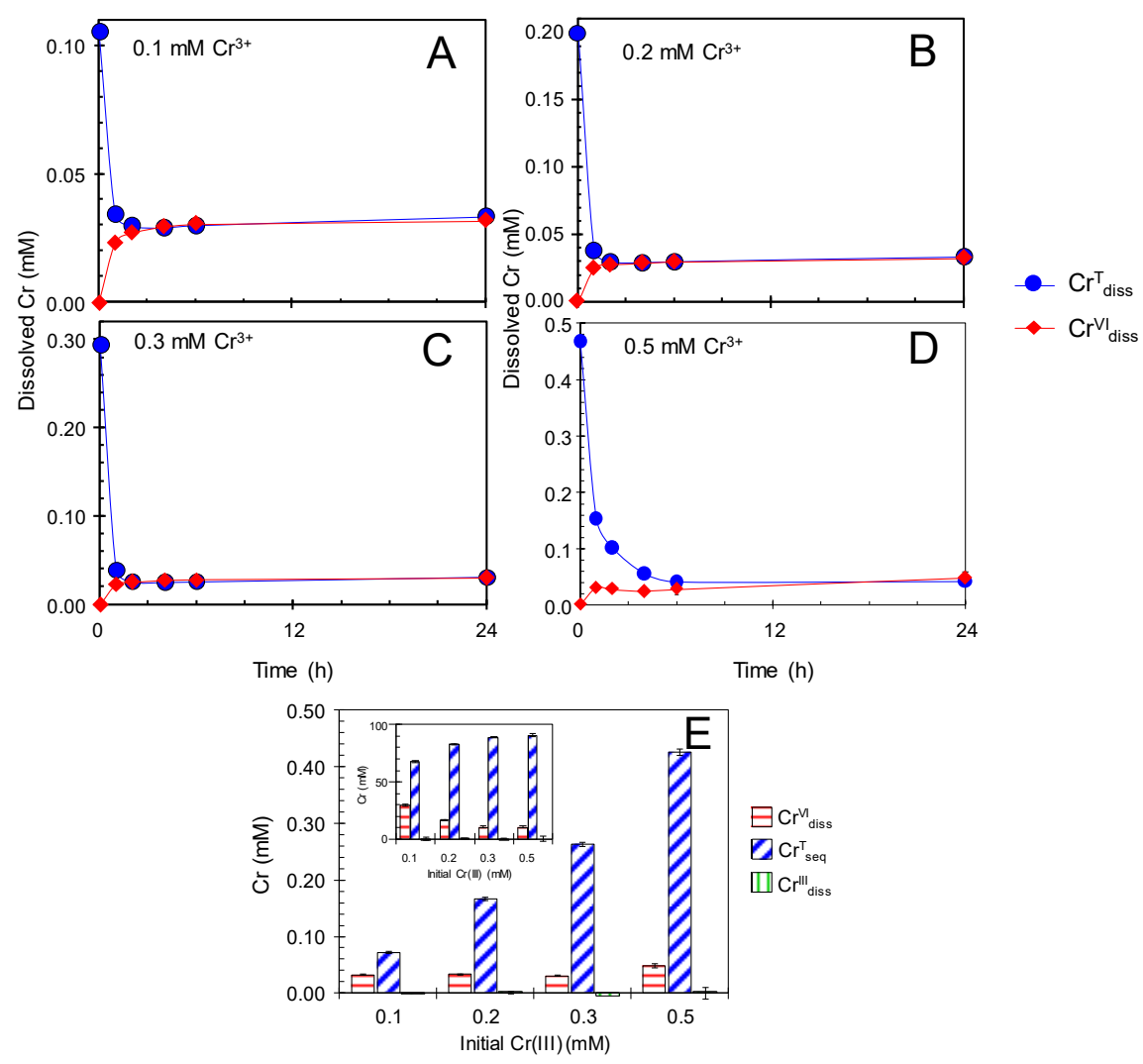

Figure 4. Single treatment of newly formed biogenic manganese oxides (BMOs; $1 \mathrm{mM}$ as $\mathrm{Mn}$ ) with 0.1-0.5 mM Cr$\left(\mathrm{NO}_{3}\right)_{3}$ under anaerobic conditions at pH 6.0 (100 mM MES buffer). (A-E) Concentrations of total $\mathrm{Cr}$ dissolved $\left(\mathrm{Cr}^{\mathrm{T}}\right.$ diss $)$ and $\mathrm{Cr}(\mathrm{VI})$ dissolved $\left(\mathrm{Cr}^{\mathrm{VI}}\right.$ diss $)$. Initial $\mathrm{Cr}\left(\mathrm{NO}_{3}\right)_{3}$ concentrations were: (A) $0.1 \mathrm{mM},(\mathbf{B}) 0.2 \mathrm{mM},(\mathbf{C}) 0.3 \mathrm{mM}$, and (D) $0.5 \mathrm{mM}$. (E) Concentrations (inset: percentages) of total Cr sequestered $\left(\mathrm{Cr}^{\mathrm{T}}{ }_{\text {seq }}\right), \mathrm{Cr}(\mathrm{VI})$ dissolved $\left(\mathrm{Cr}^{\mathrm{VI}}\right.$ diss $)$, and $\mathrm{Cr}(\mathrm{III})$ dissolved $\left(\mathrm{Cr}^{\mathrm{III}}{ }_{\text {diss }}\right)$ after the treatments. Data are shown as mean \pm standard deviation $(n=3)$. 

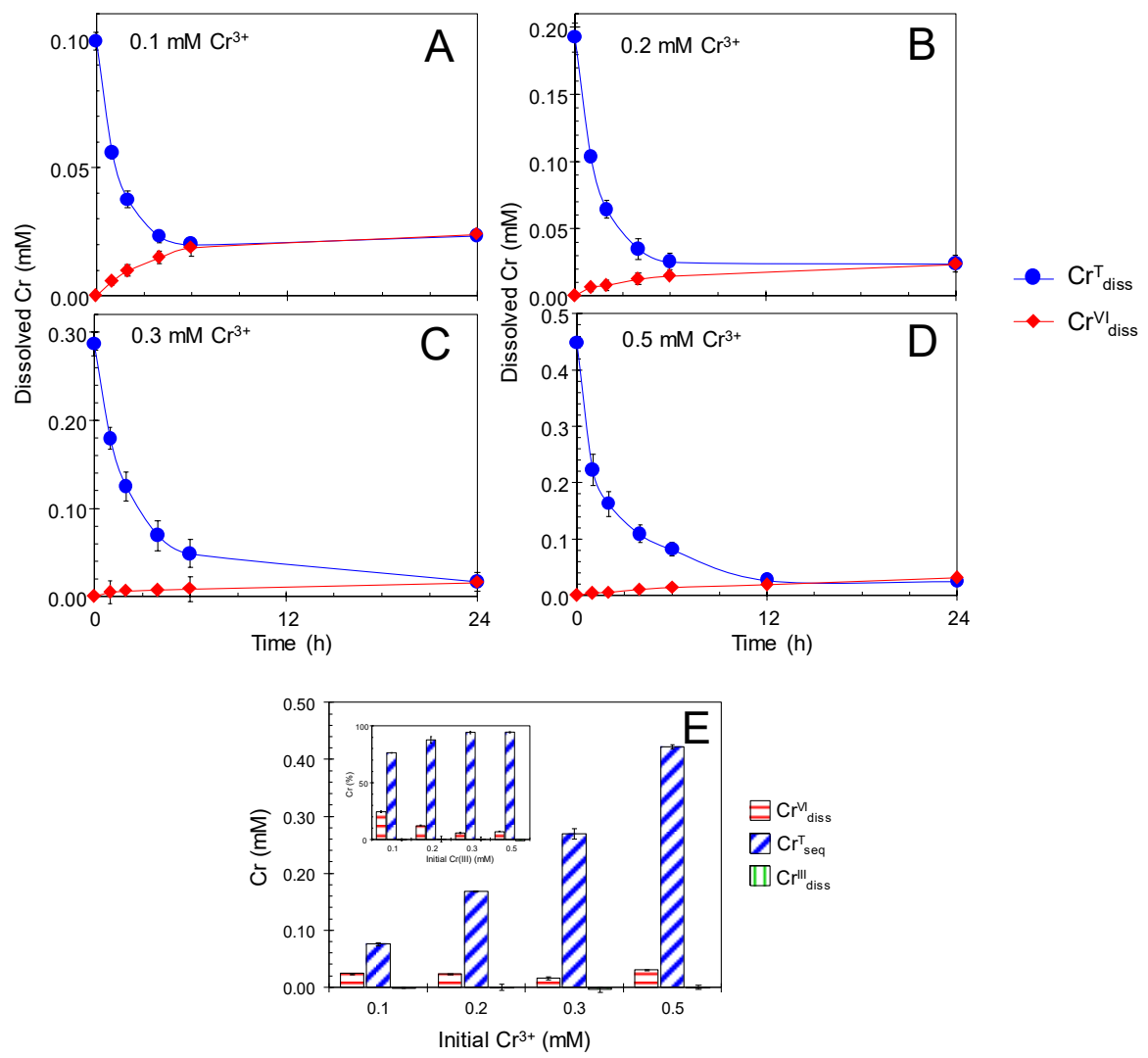

Figure 5. Single treatment of heated biogenic manganese oxides (BMOs; $1 \mathrm{mM}$ as $\mathrm{Mn}$ ) with $0.1-0.5 \mathrm{mM}$ $\mathrm{Cr}\left(\mathrm{NO}_{3}\right)_{3}$ under aerobic conditions at pH 6.0 (100 mM MES buffer). (A-E) Concentrations of total $\mathrm{Cr}$ dissolved $\left(\mathrm{Cr}^{\mathrm{T}}\right.$ diss $)$ and $\mathrm{Cr}(\mathrm{VI})$ dissolved $\left(\mathrm{Cr}^{\mathrm{VI}}\right.$ diss $)$. Initial $\mathrm{Cr}\left(\mathrm{NO}_{3}\right)_{3}$ concentrations were: (A) $0.1 \mathrm{mM}$, (B) $0.2 \mathrm{mM}$, (C) $0.3 \mathrm{mM}$, and (D) $0.5 \mathrm{mM}$. (E) Concentrations (inset: percentages) of total Cr sequestered $\left(\mathrm{Cr}^{\mathrm{T}}{ }_{\text {seq }}\right), \mathrm{Cr}(\mathrm{VI})$ dissolved $\left(\mathrm{Cr}^{\mathrm{VI}}{ }_{\text {diss }}\right)$, and $\mathrm{Cr}(\mathrm{III})$ dissolved $\left(\mathrm{Cr}^{\mathrm{III}}{ }_{\text {diss }}\right)$ after the treatments. Data are shown as mean \pm standard deviation $(n=3)$.

Interestingly, this first phase $(\sim 2 \mathrm{~h})$ of the anaerobic reaction involved the sequestration process of total $\mathrm{Cr}$ concentration $\left(\mathrm{Cr}^{\mathrm{T}}\right.$ diss ) until $\mathrm{Cr}^{\mathrm{T}}$ diss became equal mostly to $\mathrm{Cr}^{\mathrm{VI}}$ diss (Figure 4). $\mathrm{Cr}(\mathrm{VI})$ does not have significant sorption affinity to either Mn oxide phase or fungal hyphae in BMOs in $100 \mathrm{mM}$ MES at pH 6.0 (Figure S2B,C). Therefore, $\mathrm{Cr}^{\mathrm{T}}$ diss sequestration in the anaerobic treatments was mostly attributable to sorption and/or precipitation of $\mathrm{Cr}$ (III) on BMOs. At circumneutral $\mathrm{pH}$ in aqueous solutions, $\mathrm{Cr}^{3+}$ can be readily hydrolyzed to form monomers such as $[\mathrm{Cr}(\mathrm{OH})]^{2+}$ and $\left[\mathrm{Cr}(\mathrm{OH})_{2}\right]^{+}$as well as oligomers as $\left[\mathrm{Cr}_{2}(\mathrm{OH})_{2}\right]^{4+},\left[\mathrm{Cr}_{3}(\mathrm{OH})_{4}\right]^{5+}$, and $\left[\mathrm{Cr}_{4}(\mathrm{OH})_{6}\right]^{6+}[46-49]$. These polynuclear $\mathrm{Cr}(\mathrm{III})$ species may eventually precipitate as $\mathrm{Cr}(\mathrm{OH})_{3}$. Fendorf et al. [22] proposed that $\mathrm{Cr}(\mathrm{OH})_{3}$ precipitate on Mn oxide surface may be a causative factor for cessation of $\mathrm{Cr}(\mathrm{III})$ oxidation by acting as a barrier to the charge transfer between $\mathrm{Cr}(\mathrm{III})$ and structural $\mathrm{Mn}(\mathrm{III}) / \mathrm{Mn}(\mathrm{V})$, and as a redox stable sink for $\mathrm{Cr}(\mathrm{III})$. In contrast, Landrot et al. $[25,26]$ observed no $\mathrm{Cr}$ precipitation on Mn oxide surfaces reacted with $\mathrm{Cr}(\mathrm{III})$ for $1 \mathrm{~h}$, at which time the $\mathrm{Cr}$ (III) oxidation had already ceased, suggesting inhibition mechanisms other than $\mathrm{Cr}(\mathrm{OH})_{3}$ precipitation were the cause for the cessation.

To check the reversibility of the cessation of $\mathrm{Cr}$ (III) oxidation by newly formed BMOs with respect to enzymatic $\mathrm{Mn}(\mathrm{II})$ activity, we conducted the single treatment of newly formed $\mathrm{BMO}$ (1 $\mathrm{mM}$ as $\mathrm{Mn}$ ) in $0.5 \mathrm{mM} \mathrm{Cr}\left(\mathrm{NO}_{3}\right)_{3}(100 \mathrm{mM}$ MES at $\mathrm{pH}$ 6.0) under anaerobic, and subsequently, aerobic conditions. During the initial anaerobic treatment, $\mathrm{Cr}^{\mathrm{VI}}$ diss production and significant $\mathrm{Mn}^{\mathrm{II}}$ rel concomitantly ceased within the first $2 \mathrm{~h}$, when the majority of the $\mathrm{Cr}^{\mathrm{III}}{ }_{\text {Int }}$ was sequestered $\left(\mathrm{Cr}^{\mathrm{T}}\right.$ seq $)$ in the solid phase (Figure 6). When the condition was switched to aerobic, $\mathrm{Cr}^{\mathrm{VI}}$ diss was rapidly produced and concomitantly $\mathrm{Mn}^{\mathrm{II}}{ }_{\text {rel }}$ disappeared from the solution phase (Figure 6). The reversible production of $\mathrm{Cr}^{\mathrm{VI}}$ diss with respect to enzymatic $\mathrm{Mn}(\mathrm{II})$ oxidation activity may deny the hypothesis that $\mathrm{Cr}(\mathrm{OH})_{3}$ 
precipitation is responsible for anaerobic cessation of $\mathrm{Cr}(\mathrm{III})$ oxidation by BMOs. Our previous studies demonstrated the anaerobic cessation of oxidative reactions of $\mathrm{As}(\mathrm{III})$ to $\mathrm{As}(\mathrm{V})$ [29] and $\mathrm{Co}(\mathrm{II})$ to $\mathrm{Co}$ (III) [30] by newly formed BMOs, whereas aerobic conditions prevented the cessation of As(III)and $\mathrm{Co}$ (II)-oxidation reactions. We assumed the anaerobic cessation of $\mathrm{Cr}(\mathrm{III})$ oxidation was due to the surface passivation by the accumulation of reduced $\mathrm{Mn}(\mathrm{II}) / \mathrm{Mn}$ (III) species at the redox reactive sites on BMOs, resulting in insufficient electron transfer from the BMO phase to the reductant species including $\mathrm{Cr}(\mathrm{III})$.

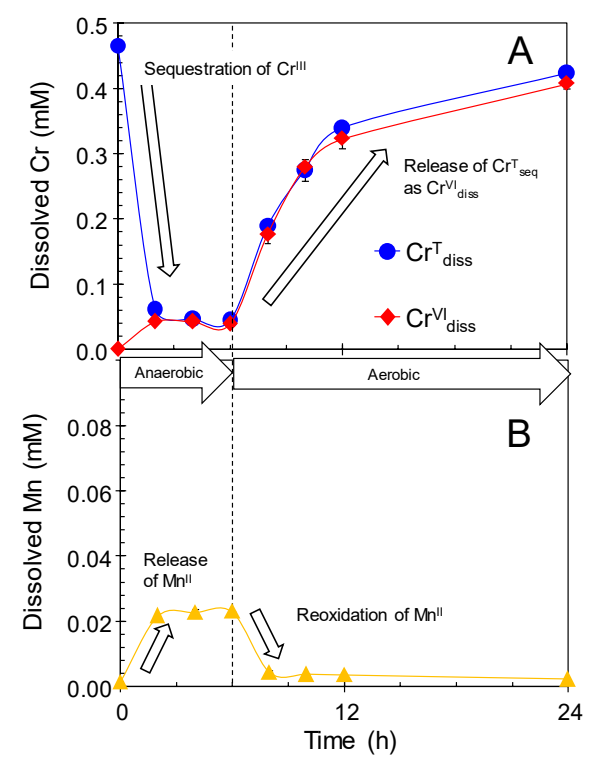

Figure 6. Concentrations of (A) total $\mathrm{Cr}$ dissolved $\left(\mathrm{Cr}^{\mathrm{T}}{ }_{\text {diss }}\right), \mathrm{Cr}(\mathrm{VI})$ dissolved $\left(\mathrm{Cr}^{\mathrm{VI}}\right.$ diss $)$, and (B) $\mathrm{Mn}(\mathrm{II})$ released $\left(\mathrm{Mn}^{\mathrm{II}}{ }_{\text {rel }}\right)$ in single treatment of newly formed $\mathrm{BMO}(1 \mathrm{mM}$ as $\mathrm{Mn})$ in $0.5 \mathrm{mM} \mathrm{Cr}\left(\mathrm{NO}_{3}\right)_{3}(100 \mathrm{mM}$ MES at pH 6.0) under anaerobic and subsequently aerobic conditions.

\subsection{Anaerobic Sequestration of Cr(III) by BMOs}

When the newly formed BMOs ( $1 \mathrm{mM}$ as $\mathrm{Mn}$ ) were repeatedly treated in anaerobic $0.5 \mathrm{mM}$ $\mathrm{Cr}\left(\mathrm{NO}_{3}\right)_{3}$ in $100 \mathrm{mM}$ MES with the renewal of the bathing solutions every $24 \mathrm{~h}$ (Figure 7 ), the cumulative $\mathrm{Cr}^{\mathrm{VI}}$ diss concentration was $0.06 \pm 0.00 \mathrm{mM}(0.03 \pm 0.00,0.01 \pm 0.00$, and $0.01 \pm 0.00 \mathrm{mM}$ for the $1 \mathrm{st}, 2 \mathrm{nd}$, and 3rd treatments, respectively), resulting in only $4 \%$ of cumulative $\mathrm{Cr}^{\mathrm{III}}$ Int oxidation (Figure 7 and Table S2). In contrast to very low oxidation efficiency, the cumulative $\mathrm{C}^{\mathrm{T}}$ seq concentration was high at $1.18 \mathrm{mM}(0.43 \pm 0.01,0.46 \pm 0.01$, and $0.14 \pm 0.00 \mathrm{mM}$ for the $1 \mathrm{st}, 2 \mathrm{nd}$, and 3rd treatments, respectively), corresponding to $83 \% \pm 1 \%$ of the cumulative $\mathrm{Cr}^{\mathrm{III}}$ Int (Figure 7 and Table S2). The molar ratio of $\mathrm{C}^{\mathrm{T}}$ seq relative to solid Mn was abnormally high $(\sim 120 \mathrm{~mol} \%)$, implying a sequestration mechanism specific to $\mathrm{Cr}$ other than the simple sorption process of common divalent heavy metal ions, $\mathrm{Zn}^{2+}$ and $\mathrm{Cd}^{2+}$ (their maximum sorption relative to solid Mn was 20-25 mol\%; [39,41]) or trivalent $\mathrm{La}^{3+}$ ions ( $30 \mathrm{~mol} \%$ [45]). Heated BMOs possessed similar Cr sequestration capacity (Figure S3) even under aerobic conditions with the domination of $\mathrm{Cr}(\mathrm{III})$ in the solid phase, which was revealed by X-ray Absorption Near-Edge Structure (XANES) (Figure 8). The XANES spectrum for the reference compound of $\mathrm{K}_{2} \mathrm{Cr}_{2} \mathrm{VI}_{7}$ showed a sharp pre-edge and a broad peak at $5988 \mathrm{eV}$ and around $6030 \mathrm{eV}$, respectively. The former peak is assigned at the $1 \mathrm{~s} \rightarrow 3 \mathrm{~d}-4 \mathrm{p}$ hybrid orbital transition and characteristic of $\mathrm{Cr}(\mathrm{VI})$ [57]. The XANES spectrum for $\mathrm{Cr} \mathrm{III}^{\mathrm{II}}\left(\mathrm{NO}_{3}\right)_{3} 9 \mathrm{H}_{2} \mathrm{O}$ has a main peak around $6005 \mathrm{eV}$, along with a pre-edge peak (the $1 \mathrm{~s} \rightarrow 3 \mathrm{~d}-4 \mathrm{p}$ hybrid orbital transition of $\mathrm{Cr}(\mathrm{III})$ ) at $5985 \mathrm{eV}$ with a much smaller intensity (Figure 8) [57]. The linear combination fit showed that $\mathrm{BMO}$ had $>95 \% \mathrm{Cr}$ (III) content after treatment in $0.5 \mathrm{mM} \mathrm{Cr}\left(\mathrm{NO}_{3}\right)_{3}$ for $24 \mathrm{~h}$. Consequently, it is likely that sorption as the polynuclear $\mathrm{Cr}(\mathrm{III})$ species would lead to abnormally high $\mathrm{Cr}$ sequestration capacity of BMO when enzymatically inactivated. The XANES spectrum also showed that domination of $\mathrm{Cr}$ (III) remained in newly formed 
BMOs at $24 \mathrm{~h}$ of the aerobic $\mathrm{Cr}(\mathrm{III})$ treatments where $>80 \%$ of $\mathrm{Cr}^{\mathrm{III}}{ }_{\text {Int }}$ was converted to $\mathrm{Cr}^{\mathrm{VI}}$ diss, strongly indicating a preferential sorption of $\mathrm{Cr}(\mathrm{III})$ over $\mathrm{Cr}(\mathrm{VI})$ on $\mathrm{BMO}$. Once $\mathrm{Cr}(\mathrm{III})$ is converted to $\mathrm{Cr}(\mathrm{VI})$ on BMO surface, it is readily leached to the solution phase as demonstrated in Figure 6.
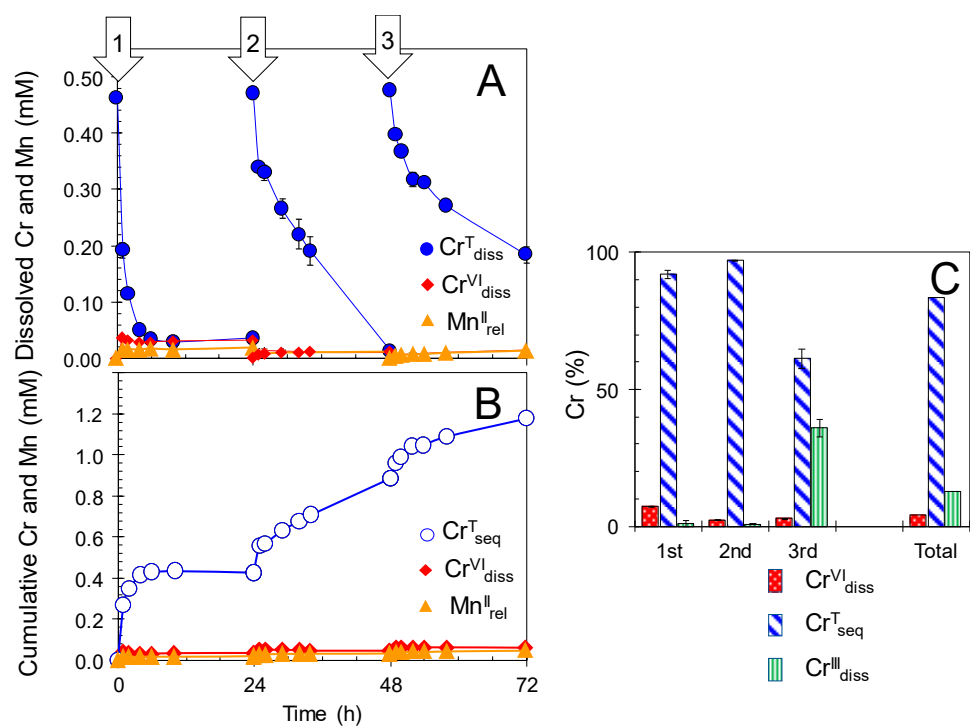

Figure 7. Repeated treatments of newly formed biogenic manganese oxides (BMOs; $1 \mathrm{mM}$ as Mn) with $0.5 \mathrm{mM} \mathrm{Cr}\left(\mathrm{NO}_{3}\right)_{3}$ under anaerobic conditions at $\mathrm{pH} 6.0$ (100 mM MES buffer). (A) Concentrations of total $\mathrm{Cr}$ dissolved $\left(\mathrm{Cr}^{\mathrm{T}}\right.$ diss $), \mathrm{Cr}(\mathrm{VI})$ dissolved $\left(\mathrm{Cr}^{\mathrm{VI}}{ }_{\text {diss }}\right)$, and $\mathrm{Mn}(\mathrm{II})$ released $\left(\mathrm{Mn}^{\mathrm{II}}{ }_{\text {rel }}\right)$. (B) Cumulative concentrations of total $\mathrm{Cr}$ sequestered $\left(\mathrm{Cr}^{\mathrm{T}}{ }_{\text {seq }}\right), \mathrm{Cr}^{\mathrm{VI}}$ diss, and $\mathrm{Mn}^{\mathrm{II}}{ }_{\text {rel }}$. (C) Percentages of $\mathrm{Cr}^{\mathrm{VI}}{ }_{\text {diss }}, \mathrm{Cr}^{\mathrm{T}}$ seq, and $\mathrm{Cr}$ (III) dissolved $\left(\mathrm{Cr}^{\mathrm{III}}{ }_{\text {diss }}\right)$ during the repeated treatments. Bathing solutions were renewed every $24 \mathrm{~h}$ for 3 days (indicated by arrows). Data are shown as mean \pm standard deviation $(\mathrm{n}=3)$.

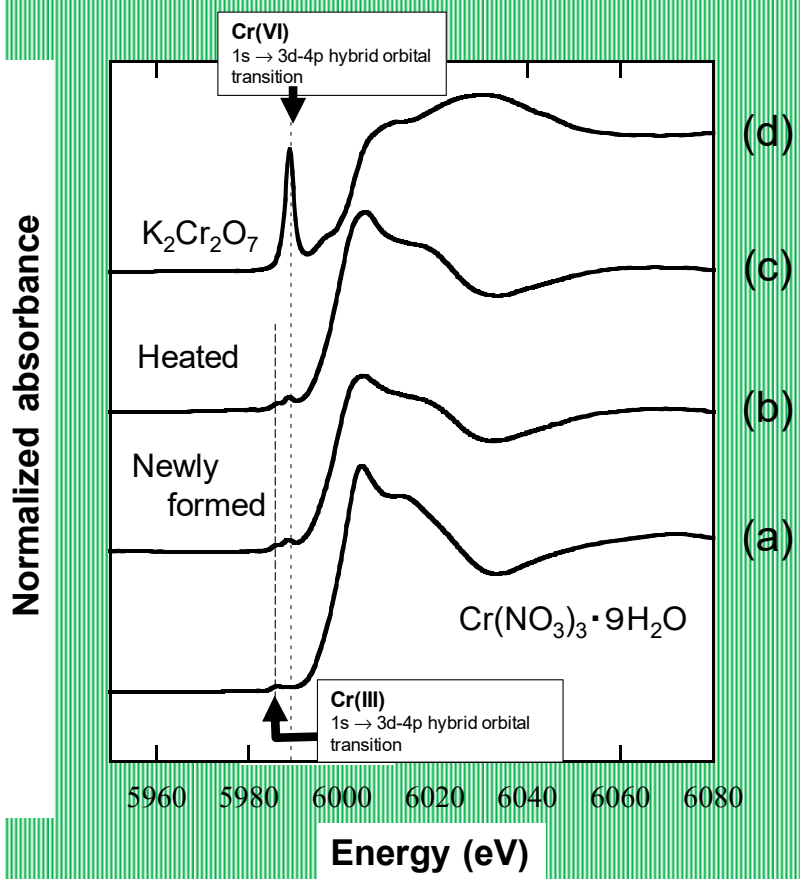

Figure 8. Cr K-edge X-ray Absorption Near-Edge Structure (XANES) of newly formed and heated BMOs treated in $0.5 \mathrm{mM} \mathrm{Cr}\left(\mathrm{NO}_{3}\right)_{3}$ solution/100 mM MES ( $\mathrm{pH}$ 6.0) for $24 \mathrm{~h}$ under aerobic condition. $\mathrm{Cr}\left(\mathrm{NO}_{3}\right)_{3} \cdot 9 \mathrm{H}_{2} \mathrm{O}$ and $\mathrm{K}_{2} \mathrm{Cr}_{2} \mathrm{O}_{7}$ represent $\mathrm{Cr}(\mathrm{III})$ and $\mathrm{Cr}(\mathrm{VI})$ references, respectively. (a) $\mathrm{Cr}_{2}\left(\mathrm{NO}_{3}\right)_{3} \cdot 9 \mathrm{H}_{2} \mathrm{O}$, (b) newly formed and (c) heated BMOs treated in $\mathrm{Cr}\left(\mathrm{NO}_{3}\right)_{3}$, and (d) $\mathrm{K}_{2} \mathrm{Cr}_{2} \mathrm{O}_{7}$. 
Newly formed BMOs produced by A. strictum KR21-2 are layered analogously to vernadite, a natural nanostructured and turbostratic variety of birnessite [32]. Prior to $0.5 \mathrm{mM} \mathrm{Cr}\left(\mathrm{NO}_{3}\right)_{3}$ treatments, no apparent changes in X-ray Diffraction (XRD) patterns were observed between newly formed and heated BMOs (Figure 9), for which the XRD peaks at 7.3, 2.4, and $1.4 \AA$ were assigned to $(001),(11,20)$, and $(31,02)$, respectively [39]. Following the treatment, heated BMO exhibited a decline in XRD intensity arising from (001) basal reflection (Figure 9), suggesting that the ordering of the vernadite (birnessite) sheet stacking was mostly disturbed by sorption of polynuclear $\mathrm{Cr}(\mathrm{III})$ species with a high proportion of $\mathrm{Cr}^{\mathrm{T}}{ }_{\text {seq }}(0.42 \pm 0.00 \mathrm{mM})$ relative to solid $\mathrm{Mn}(1 \mathrm{mM}$ as $\mathrm{Mn})$. In contrast, newly formed BMOs maintained a (001) XRD intensity even after the treatments (Figure 9) where much less $\mathrm{Cr}^{\mathrm{T}}$ seq remained in the solid $(0.06 \pm 0.02 \mathrm{mM})$. High sorption affinity of BMO for polynuclear $\mathrm{Cr}(\mathrm{III})$ species should play an as important role in efficient $\mathrm{Cr}$ (III) oxidation in aerobic treatments because significant amounts of $\mathrm{Cr}$ sequestration (i.e., a decrease in $\mathrm{Cr}^{\mathrm{T}}$ diss in Figure 1) progressed concomitantly with $\mathrm{Cr}^{\mathrm{VI}}$ diss production.

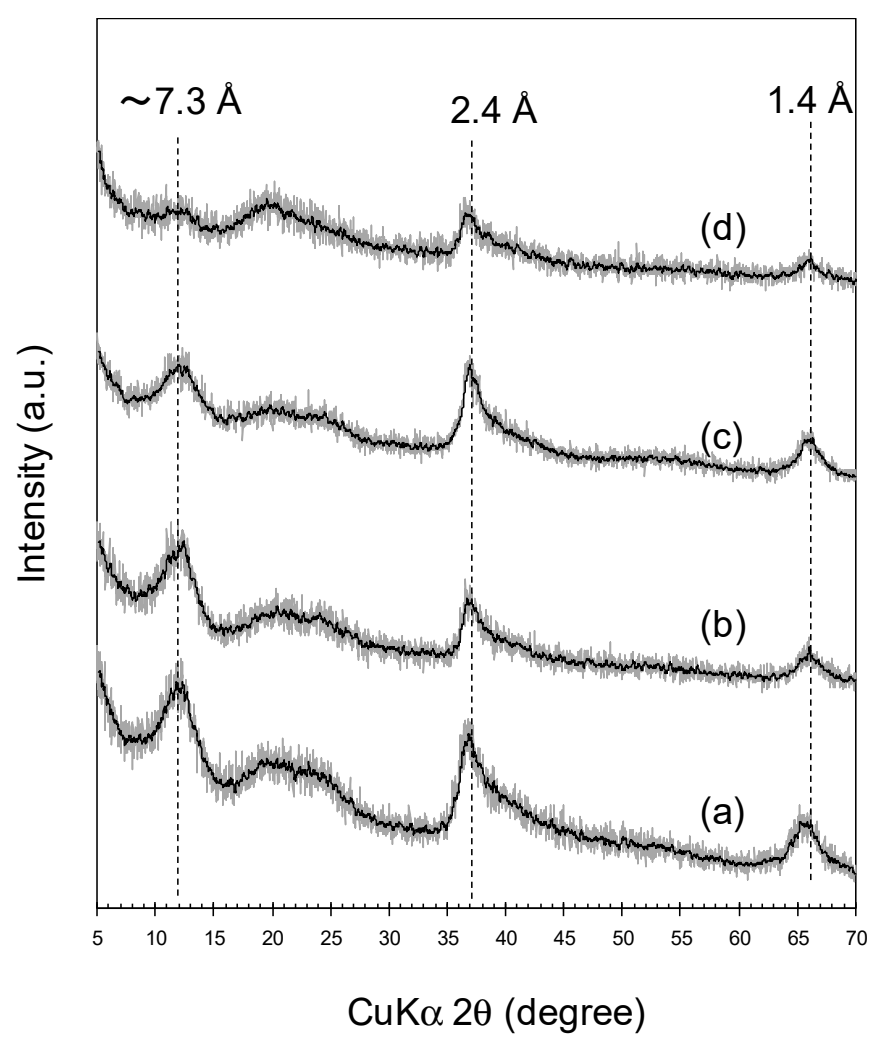

Figure 9. X-ray Diffraction (XRD) of newly formed and heated BMOs before and after treatments in $0.5 \mathrm{mM} \mathrm{Cr}\left(\mathrm{NO}_{3}\right)_{3} / 100 \mathrm{mM}$ MES (pH 6.0) for $24 \mathrm{~h}$ under aerobic condition. Newly formed BMOs (a) before and (b) after the treatments, and heated BMOs (c) before and (d) after the treatments.

\section{Materials and Methods}

\subsection{Formation of Fungal BMOs by A. strictum KR21-2}

Acremonium strictum KR21-2, which is capable of enzymatically oxidizing Mn(II) to BMO [51,52], was grown in HAY liquid medium (20 mM 4-(2-hydroxyethyl)-1-piperazineethanesulphonic acid (HEPES) buffer ( $\mathrm{pH} 7.0$ ) with $1 \mathrm{mM} \mathrm{MnSO}_{4}$ ) as reported previously [27,30,39,41].

\subsection{Cr(III)-Oxidizing Ability of Newly Formed and Heated BMOs at $\mathrm{pH} 6.0$}

After incubating A. strictum KR21-2 in $1 \mathrm{mM} \mathrm{Mn}^{2+}$-supplemented HAY medium (pH 7.0) for $72 \mathrm{~h}$, the solid phase (biooxide plus fungal mycelia; hereafter designated "newly formed $\mathrm{BMO}^{\text {") }}$ was 
harvested, washed with $100 \mathrm{mM}$ 2-morpholinoethanesulfonic acid (MES) buffer ( $\mathrm{pH}$ 6.0) three times, and treated with $0.1-0.5 \mathrm{mM} \mathrm{Cr}\left(\mathrm{NO}_{3}\right)_{3}$ in $100 \mathrm{mM}$ MES (pH 6.0) for $24 \mathrm{~h}$. To monitor the abilities of $\mathrm{Cr}$ (III) oxidation and sequestration of newly formed BMO under air-equilibrated (aerobic) and $\mathrm{N}_{2}$ gas-purged (anaerobic) conditions as reported previously $[30,39,41]$. Supernatants were sampled at 0 , $2,4,8$, and $24 \mathrm{~h}$, separated by centrifugation (11,000 $\mathrm{g}$ for $2 \mathrm{~min}$ ), and preserved in $2 \% \mathrm{HNO}_{3}$. Total $\mathrm{Cr}(\mathrm{III})$ and $\mathrm{Cr}(\mathrm{VI})$ concentrations were analyzed by a Varian 730-ES inductively coupled plasma-atomic emission spectrometer (ICP-AES) (Agilent Inc., Santa Clara, CA, USA). The Cr(VI) concentrations were determined by colorimetric method according to Urone [58], and Bartlett and James [59]. Newly formed BMOs were enzymatically inactivated by being heated at $85^{\circ} \mathrm{C}$ for $1 \mathrm{~h}$ in a liquid culture medium using a water bath (Thermo Minder Mini-80, Taitec Corp., Koshigaya, Japan), allowed to cool to room temperature before use (hereafter designated "heated $\mathrm{BMO}^{\text {"; }}$ [27]), and then used for $\mathrm{Cr}$ (III) oxidation experiments with $0.1-0.5 \mathrm{mM} \mathrm{Cr}\left(\mathrm{NO}_{3}\right)_{3}$ in $100 \mathrm{mM}$ MES ( $\mathrm{pH}$ 6.0) under aerobic conditions.

Repeated treatment experiments were also carried out with renewal of the bathing solutions $(0.1$ or $0.5 \mathrm{mM} \mathrm{Cr}\left(\mathrm{NO}_{3}\right)_{3}$ solution with $\left.100 \mathrm{mM} \mathrm{MES}\right)$ every $24 \mathrm{~h}$ under aerobic and anaerobic conditions.

\subsection{X-ray Absorption Near-Edge Structure (XANES) Spectroscopy}

Chromium K-edge XANES spectra were collected at the beamline 12C at the Photon Factory, KEK (Tsukuba, Japan). Newly formed (enzymatically active) and heated (enzymatically inactive) BMOs were treated with $0.5 \mathrm{mM} \mathrm{Cr}\left(\mathrm{NO}_{3}\right)_{3}$ in $100 \mathrm{mM}$ MES $(\mathrm{pH}=6.0)$ for under aerobic condition $(24 \mathrm{~h})$, harvested and lyophilized. As references for $\mathrm{Cr}(\mathrm{VI})$ and $\mathrm{Cr}(\mathrm{III})$ species, aqueous solutions of $\mathrm{K}_{2} \mathrm{Cr}_{2} \mathrm{O}_{7}$ and $\mathrm{Cr}\left(\mathrm{NO}_{3}\right)_{3} \cdot 9 \mathrm{H}_{2} \mathrm{O}$, were measured respectively. The storage ring was operated at $2.5 \mathrm{GeV}$ with a typical beam current of $450 \mathrm{~mA}$. The incident $X$-ray beam was obtained by monochromatization of the broad band synchrotron radiation from the storage ring with a $\mathrm{Si}$ (111) double-crystal monochromator. The beam size of the incident $X$-ray was focused into an area $1 \times 1 \mathrm{~mm}^{2}$ at the sample position. The spectra of the reference solutions and the BMO samples were collected in transmission mode using ionization chambers.

\subsection{Powder X-ray Diffraction (XRD)}

The XRD measurements BMOs were carried out after single treatment experiments with $0.5 \mathrm{mM}$ $\mathrm{Cr}\left(\mathrm{NO}_{3}\right)_{3}$ in $100 \mathrm{mM} \mathrm{MES}(\mathrm{pH}=6.0)$ for newly formed (enzymatically active) and heated (enzymatically inactive) BMOs under aerobic condition $(24 \mathrm{~h})$. Treated BMOs were harvested, and lyophilized. A RINT-2500 diffractometer (Rigaku Corp., Tokyo, Japan) was used with CuK $\alpha$ radiation at $26 \mathrm{~mA}$ and $40 \mathrm{kV}$. The scanning range was from $5^{\circ}$ to $70^{\circ}$ of $2 \theta$ and scanning rate was $1.0^{\circ} \mathrm{min}^{-1}$ with a step interval of $0.02^{\circ}$. The diffractograms were smoothed by the 10-point moving average method to display broad peaks more clearly.

\section{Conclusions}

The results presented here demonstrate that under aerobic conditions, enzymatically active BMOs efficiently mediate oxidation of $\mathrm{Cr}(\mathrm{III})$ to $\mathrm{Cr}(\mathrm{VI})$ without releasing reduced $\mathrm{Mn}$ (II) at $\mathrm{pH}$ 6.0. Thus, enzymatically active BMOs may aerobically leach (remove) $\mathrm{Cr}$ from the $\mathrm{Cr}$ (III)-contaminated sites, through catalytic oxidation to more labile $\mathrm{Cr}(\mathrm{VI})$. In contrast, $\mathrm{Cr}(\mathrm{III})$ oxidation readily ceases under anaerobic conditions due to the surface passivation of BMOs, whereas sequestration of $\mathrm{Cr}$ (III) (most probably as polynuclear $\mathrm{Cr}$ (III) species) progresses with extraordinary sequestration capacity of $\mathrm{Cr}$ (III) (up to $120 \%$ mol of $\mathrm{Cr}$ relative to solid Mn). This shows the potential applicability of BMOs as an efficient sorbent for $\mathrm{Cr}(\mathrm{III})$ from wastewater at a circumneutral $\mathrm{pH}$. Interestingly, anaerobically sequestered $\mathrm{Cr}$ (III) can subsequently be released by switching to aerobic conditions, through the catalytic (enzymatic) Mn oxidation cycles by BMOs. These findings provide supporting evidence for the potential applications of BMOs towards the recovery of $\mathrm{Cr}$ species from industrial wastewater (anaerobic $\mathrm{Cr}$ sequestration) and environmental remediation of $\mathrm{Cr}$-contaminated sites (aerobic oxidative Cr leaching). 
Supplementary Materials: The following are available online at http://www.mdpi.com/2073-4344/10/1/44/s1, Abbreviations, Figure S1: Release of $\mathrm{Mn}(\mathrm{II})$ during single treatments of BMOs in $\mathrm{Cr}\left(\mathrm{NO}_{3}\right)_{3}$. Figure S2: Stability of dissolved $0.5 \mathrm{mM} \mathrm{Cr}\left(\mathrm{NO}_{3}\right)_{3}$, and sorption of $\mathrm{Cr}(\mathrm{VI})$ on BMOs, Figure S3: Repeated treatments of heated BMOs in aerobic $\mathrm{Cr}\left(\mathrm{NO}_{3}\right)_{3}$, Table S1: Summary of single treatment experiments of BMOs in $\mathrm{Cr}\left(\mathrm{NO}_{3}\right)_{3}$, Table S2: Summary of repeated treatments of $\mathrm{BMOs}$ in $\mathrm{Cr}\left(\mathrm{NO}_{3}\right)_{3}$.

Author Contributions: Conceptualization, R.S. and Y.T.; methodology, Y.T., N.M. and K.T.; Characterization, R.S., H.N., N.M. and K.T.; investigation, R.S. and H.N.; writing-original draft preparation, R.S. and Y.T.; writing-review and editing, R.S. and Y.T.; visualization, R.S. and Y.T.; supervision, Y.T.; funding acquisition, Y.T. All authors have read and agreed to the published version of the manuscript.

Funding: This work was supported by The Salt Science Research Foundation, No. 1907 (Y.T.), and the Japan Society for the Promotion of Science KAKENHI, No. 16K00615 (Y.T.).

Acknowledgments: The authors would like to thank The Salt Science Research Foundation, and the Japan Society for the Promotion of Science KAKENHI for the research funding and Editage for providing editorial assistance. Chromium K-edge XANES measurement was performed with the approval of the Photon Factory, KEK (Proposal No. 2018G111).

Conflicts of Interest: The authors declare no conflict of interest.

\section{References}

1. Zayed, A.M.; Terry, N. Chromium in the environment: Factors affecting biological remediation. Plant Soil 2003, 249, 139-156. [CrossRef]

2. Oliveira, H. Chromium as an environmental pollutant: Insights on induced plant toxicity. J. Bot. 2012, 2012, 375843. [CrossRef]

3. Sun, H.; Brocato, J.; Costa, M. Oral chlomium exposure and toxicity. Curr. Environ. Health Rep. 2015, 2, 295-303. [CrossRef] [PubMed]

4. Aslam, S.; Yousafzai, A.M. Chromium toxicity in fish: A review article. J. Entomol. Zool. Stud. 2017, 5, 1483-1488.

5. Babula, P.; Adam, V.; Opatrilova, R.; Zehnalek, J.; Havel, L.; Kizek, R. Uncommon heavy metals, metalloids and their plant toxicity: A review. Environ. Chem. Lett. 2008, 6, 189-213. [CrossRef]

6. Diwan, H.; Ahmad, A.; Iqbal, M. Characterization of chromium toxicity in food crops and their role in phytoremediation. J. Bioremed. Biodegrad. 2012, 3, 1000159. [CrossRef]

7. Shahid, M.; Shamshad, S.; Rafiq, M.; Khalid, S.; Bibi, I.; Niazi, N.K.; Dumat, C.; Rashid, M.I. Chromium speciation, bioavailability, uptake, toxicity and detoxification in soil-plant systems: A review. Chemosphere 2017, 178, 513-533. [CrossRef]

8. Bartlett, R.J. Chromium cycling in soils and water: Links, gaps, and methods. Environ. Health Perspect. 1991, 92, 17-24. [CrossRef]

9. Adriano, D.C.; Wenzel, W.W.; Vangronsveld, J.; Bolan, N.S. Role of assisted natural remediation in environmental cleanup. Geoderma 2004, 122, 121-142. [CrossRef]

10. Tebo, B.M.; Bargar, J.R.; Clement, B.G.; Dick, G.J.; Murray, K.J.; Parker, D.; Verity, R.; Webb, S.M. Biogenic manganese oxides: Properties and mechanisms of formation. Annu. Rev. Earth Planet. Sci. 2004, 32, $287-328$. [CrossRef]

11. Miyata, N.; Tani, Y.; Sakata, M.; Iwahori, K. Microbial manganese oxide formation and interaction with toxic metal ions. J. Biosci. Bioeng. 2007, 104, 1-8. [CrossRef]

12. Tani, Y.; Miyata, N.; Iwahori, K.; Soma, M.; Tokuda, S.; Seyama, H.; Theng, B.K.G. Biogeochemistry of manganese oxide coatings on pebble surfaces in the Kikukawa River System, Shizuoka, Japan. Appl. Geochem. 2003, 18, 1541-1554. [CrossRef]

13. Furuta, S.; Ikegaya, H.; Hashimoto, H.; Ichise, S.; Kohno, T.; Miyata, N.; Takada, J. Formation of filamentous Mn oxide particles by the alphaproteobacterium Bosea sp. strain BIWAKO-01. Geomicrobiol. J. 2015, 32, 666-676. [CrossRef]

14. Cahyani, V.R.; Murase, J.; Ishibashi, E.; Asakuwa, S.; Kimura, M. Phylogenetic positions of $\mathrm{Mn}^{2+}$-oxidizing bacteria and fungi isolated from Mn nodules in rice field subsoils. Biol. Fertil. Soils 2009, 45, 337-346. [CrossRef] 
15. Miller, A.Z.; Dionisio, A.; Braga, M.A.S.; Hernandez-Marine, M.; Afonso, M.J.; Muralha, V.S.F.; Herrera, L.K.; Raabe, J.; Fernandez-Cortes, A.; Cuezva, S.; et al. Biogenic Mn oxide minerals coating in a subsurface granite environment. Chem. Geol. 2012, 322-323, 181-191. [CrossRef]

16. Ivarsson, M.; Broman, C.; Gustafsson, H.; Holm, N.G. Biogenic Mn-oxide in subseafloor basalts. PLoS ONE 2015, 10, e0128863. [CrossRef]

17. Murray, K.J.; Mozafarzadeh, M.L.; Tebo, B.M. $\mathrm{Cr}$ (III) oxidation and $\mathrm{Cr}$ toxicity in cultures of the manganese(II)-oxidizing Pseudomonas putida strain GB-1. Geomicrobiol. J. 2005, 22, 151-159. [CrossRef]

18. Wu, Y.; Deng, B.; Xu, H.; Kornishi, H. Chromium(III) oxidation coupled with microbially mediated Mn(II) oxidation. Geomicrobiol. J. 2005, 22, 161-170. [CrossRef]

19. Murray, K.J.; Tebo, B.M. Cr(III) is indirectly oxidized by the Mn(II)-oxidizing bacterium Bacillus sp. strain SG-1. Environ. Sci. Technol. 2007, 41, 528-533. [CrossRef]

20. He, J.Z.; Meng, Y.T.; Zheng, Y.M.; Zhang, L.M. Cr(III) oxidation coupled with Mn(II) bacterial oxidation in the environment. J. Soils Sediments 2010, 10, 767-773. [CrossRef]

21. Tang, Y.; Webb, S.M.; Estes, E.R.; Hansel, C.M. Chromium(III) oxidation by biogenic manganese oxides with varying structural ripening. Environ. Sci. Process. Impacts 2014, 16, 2127-2136. [CrossRef]

22. Fendorf, S.E.; Fendorf, M.; Spaeks, D.L.; Gronsky, R. Inhibitory mechanisms of Cr(III) oxidation by d-MnO $\mathrm{M}_{2}$ J. Colloid Interface Sci. 1992, 153, 37-54. [CrossRef]

23. Fendorf, S.E.; Zasoski, R.J. Chromium(III) oxidation by d-MnO 2.1 . Characterization. Environ. Sci. Technol. 1992, 26, 79-85. [CrossRef]

24. Stepniewska, Z.; Bucior, K.; Bennicelli, R.P. The effect of $\mathrm{MnO} 2$ on sorption and oxidation of $\mathrm{Cr}$ (III) by soils. Geoderma 2004, 122, 291-296. [CrossRef]

25. Landrot, G.; Ginder-Vogel, M.; Livi, K.; Fitts, J.P.; Sparks, D.L. Chromium(III) oxidation by three poorly-crystalline manganese(IV) oxides. 1. Chromium(III)-oxidizing capacity. Environ. Sci. Technol. 2012, 46, 11594-11600. [CrossRef]

26. Landrot, G.; Ginder-Vogel, M.; Livi, K.; Fitts, J.P.; Sparks, D.L. Chromium(III) oxidation by three poorly-crystalline manganese(IV) oxides. 2. Solid phase analyses. Environ. Sci. Technol. 2012, 46, 11601-11609. [CrossRef]

27. Chang, J.; Tani, Y.; Naitou, H.; Miyata, M.; Seyama, H. Fungal Mn oxides supporting Mn(II) oxidase activity as effective Mn(II) sequestering materials. Environ. Technol. 2013, 34, 2781-2787. [CrossRef]

28. Tani, Y.; Miyata, N.; Ohashi, M.; Ohnuki, T.; Seyama, H.; Iwahori, K.; Soma, M. Interaction of inorganic arsenic with biogenic manganese oxide produced by a Mn-oxidizing fungus, strain KR21-2. Environ. Sci. Technol. 2004, 38, 6618-6624. [CrossRef]

29. Watanabe, J.; Tani, Y.; Chang, J.; Miyata, N.; Naitou, H.; Seyama, H. As(III) oxidation kinetics of biogenic manganese oxides formed by Acremonium strictum strain KR21-2. Chem. Geol. 2013, 347, 227-232. [CrossRef]

30. Chang, J.; Tani, Y.; Naitou, H.; Miyata, N.; Seyama, H.; Tanaka, K. Cobalt(II) sequestration on fungal biogenic manganese oxide enhanced by manganese(II) oxidase activity. Appl. Geochem. 2013, 37, 170-178. [CrossRef]

31. Villalobos, M.; Bargar, J.; Sposito, G. Trace metal retention on biogenic manganese oxide nanoparticles. Elements 2005, 1, 223-226. [CrossRef]

32. Grangeon, S.; Lanson, B.; Miyata, N.; Tani, Y.; Manceau, A. Structure of nanocrystalline phyllomanganates produced by freshwater fungi. Am. Mineral. 2010, 95, 1608-1616. [CrossRef]

33. Nelson, Y.M.; Lion, L.W.; Ghiorse, W.C.; Shuler, M.L. Production of biogenic Mn oxides by Leprothrix discophora SS-1 in a chemically defined growth medium and evaluation of their Pb adsorption characteristics. Appl. Environ. Microbiol. 1999, 65, 175-180. [CrossRef] [PubMed]

34. Nelson, Y.M.; Lion, L.W.; Shuler, M.L.; Ghiorse, W.C. Effect of oxide formation mechanisms on lead adsorption by biogenic manganese (hydr)oxides, iron (hydr)oxides, and their mixtures. Environ. Sci. Technol. 2002, 36, 421-425. [CrossRef]

35. Villalobos, M.; Bargar, J.; Sposito, G. Mechanism of $\mathrm{Pb}(\mathrm{II})$ sorption on a biogenic manganese oxide. Environ. Sci. Technol. 2005, 39, 569-576. [CrossRef]

36. Toner, B.; Manceau, A.; Webb, S.M.; Sposito, G. Zinc sorption to biogenic hexagonal birnessite particles within a hydrated bacterial biofilm. Geochim. Cosmochim. Acta 2006, 70, 27-43. [CrossRef]

37. Wang, W.M.; Shao, Z.Z.; Liu, Y.J.; Wang, G.J. Removal of multi-heavy metals using biogenic manganese oxides generated by a deep-sea sedimentary bacterium Brachybacterium sp. strain Mn32. Microbiology 2009, 155, 1989-1996. [CrossRef] 
38. Yu, Q.; Sasaki, K.; Tanaka, K.; Ohnuki, T.; Hirajima, T. Zinc sorption during bio-oxidation and precipitation of manganese modifies the layer stacking of biogenic birnessite. Geomicrobiol. J. 2013, 30, 829-839. [CrossRef]

39. Chang, J.; Tani, Y.; Naitou, H.; Miyata, M.; Tojo, F.; Seyama, H. Zn(II) sequestration by fungal biogenic manganese oxide through enzymatic and abiotic processes. Chem. Geol. 2014, 383, 155-163. [CrossRef]

40. Meng, Y.T.; Zheng, Y.M.; Zhang, L.M.; He, J.Z. Biogenic Mn oxides for effective adsorption of Cd from aquatic environment. Environ. Pollut. 2009, 157, 2577-2583. [CrossRef]

41. Chang, J.; Tani, Y.; Naitou, H.; Miyata, N.; Seyama, H.; Tanaka, K. Sequestration of Cd(II) and Ni(II) ions on fungal manganese oxides associated with Mn(II) oxidase activity. Appl. Geochem. 2014, 47, 198-208. [CrossRef]

42. Zhu, M.Q.; Ginder-Vogel, M.; Sparks, D.L. Ni(II) sorption on biogenic Mn-oxides with varying Mn octahedral layer structure. Environ. Sci. Technol. 2010, 44, 4472-4478. [CrossRef] [PubMed]

43. Sasaki, K.; Kaseyama, T.; Hirajima, T. Selective sorption of Co(II) over Ni(II) using biogenic manganese oxides. Mater. Trans. 2009, 50, 2643-2648. [CrossRef]

44. Yu, Q.; Ohnuki, T.; Tanaka, K.; Kozai, N.; Yamasaki, S.; Sakamoto, F.; Tani, Y. Fungal-promoted transformation of lanthanides during the biooxidation of divalent manganese. Geochim. Cosmochim. Acta. 2016, 174, 1-12. [CrossRef]

45. Zheng, H.; Tani, Y.; Naitou, H.; Miyata, N.; Tojo, F.; Seyama, H. Sequestration of La3+ by fungal manganese oxides and the effect of Mn(II) oxidase activity. J. Environ. Chem. Eng. 2017, 5, 735-743. [CrossRef]

46. Stunzi, H.; Rotzinger, F.P.; Marty, W. Early stages of the hydrolysis of chromium(III) in aqueous solution. 2. Kinetics and mechanism of the interconversion between two tetrametric species. Inorg. Chem. 1984, 23, 2160-2164. [CrossRef]

47. Stunzi, H.; Marty, W. Early stages of the hydrolysis of chromium(III) in aqueous solution. 1. Characterization of a tetrameric species. Inorg. Chem. 1983, 22, 2145-2150. [CrossRef]

48. Saleh, F.Y.; Mbamalu, G.E.; Brungardt, C.E. Ion chromatography-photodiode arra UV-visible detection of $\mathrm{Cr}$ (III) hydrolytic polymerization products in pure and natural waters. Anal. Chem. 1996, 68, 740-745. [CrossRef]

49. Rao, L.; Zhang, Z.; Friese, J.I.; Ritherdon, B.; Clark, S.B.; Hess, N.J.; Rai, D. Oligomerization of chromium(III) and its impact on the oxidation of chromium(III) by hydrogen peroxide in alkaline solutions. J. Chem. Soc. Dalton Trans. 2002, 267-274. [CrossRef]

50. Hu, L.; Cai, Y.; Jiang, G. Occurrence and speciation of polymeric chromium(III), monomeric chromium(III) and chromium(VI) in environment samples. Chemosphere 2016, 156, 14-20. [CrossRef]

51. Miyata, N.; Tani, Y.; Iwahori, K.; Soma, M. Enzymatic formation of manganese oxides by an Acremonium-like hyphomycete fungus, strain KR21-2. FEMS Microbiol. Ecol. 2004, 47, 101-109. [CrossRef]

52. Miyata, N.; Tani, Y.; Maruo, K.; Tsuno, H.; Sakata, M.; Iwahori, K. Manganese(IV) oxide production by Acremonium sp. strain KR21-2 and extracellular Mn(II) oxidase activity. Appl. Environ. Microbiol. 2006, 72, 6467-6473. [CrossRef] [PubMed]

53. Inthorn, D.; Tani, Y.; Chang, J.; Naitou, H.; Miyata, N. Magnetically modified fungal Mn oxides with high sequestration efficiency for simultaneously removing multiple heavy metal ions from wastewater. J. Environ. Chem. Eng. 2014, 2, 1635-1641. [CrossRef]

54. Zheng, H.; Tani, Y.; Naitou, H.; Miyata, N.; Tojo, F. Oxidative $\mathrm{Ce}^{3+}$ sequestration on fungal manganese oxides with an associated Mn(II) oxidase activity. Appl. Geochem. 2016, 71, 110-122. [CrossRef]

55. Elyahyaoui, A.; Ellouzi, K.; Zabadi, H.A.; Razzouki, B.; Bouhlassa, S.; Azzaoui, K.; Mejdoubi, E.M.; Hamed, O.; Jodeh, S.; Lamhamdi, A. Adsorption of chromium(VI) on calcium phosphate: Mechanisms and stability constants of surface complexes. Appl. Sci. 2017, 7, 222. [CrossRef]

56. Grossl, P.R.; Eick, M.; Spark, D.L.; Goldberg, S.; Ainsworth, C.C. Arsenate and chromate retention mechanisms on goethite. 2. Kinetic evaluation using a pressure-jump relaxation technique. Environ. Sci. Technol. 1997, 31, 321-326. [CrossRef]

57. Ohta, A.; Kagi, H.; Tsuno, H.; Nomura, M.; Okai, T. Speciation study of Cr(VI/III) reacting with humic substances and determination of local structure of $\mathrm{Cr}$ binding humic substances using XAFS spectroscopy. Geochem. J. 2012, 46, 409-420. [CrossRef] 
58. Urone, P.E. Stability of colorimetric reagent for chromium, S-diphenylcarbazides, in various solvents. Anal. Chem. 1955, 27, 1354-1355. [CrossRef]

59. Bartlett, R.J.; James, J.M. Behavior of chromium in soil III. Oxidation. J. Environ. Qual. 1979, 8, 31-35. [CrossRef]

(c)

(C) 2019 by the authors. Licensee MDPI, Basel, Switzerland. This article is an open access article distributed under the terms and conditions of the Creative Commons Attribution (CC BY) license (http://creativecommons.org/licenses/by/4.0/). 